\title{
Service Quality of Mobile Banking Services in ICICI Bank Limited
}

\author{
R. Ayswarya1, D. Sarala1, P. Muralidharan², M. Ilankadhir ${ }^{3}$ \\ ${ }^{1}$ PG \& Research Department of Commerce, Cauvery College for Women \\ (Autonomous), Tiruchirappalli, India \\ ${ }^{2}$ Department of Commerce, St. Joseph's College of Commerce (Autonomous), Bangalore, India \\ ${ }^{3}$ School of Management Studies, Sathyabama Institute of Science and Technology, Chennai, India \\ Email: aysi.ayswarya@gmail.com
}

How to cite this paper: Ayswarya, R., Sarala, D., Muralidharan, P. and Ilankadhir, M. (2019) Service Quality of Mobile Banking Services in ICICI Bank Limited. Journal of Service Science and Management, 12, 649-664.

https://doi.org/10.4236/jssm.2019.125045

Received: July 10, 2019

Accepted: August 16, 2019

Published: August 19, 2019

Copyright (c) 2019 by author(s) and Scientific Research Publishing Inc. This work is licensed under the Creative Commons Attribution International License (CC BY 4.0).

http://creativecommons.org/licenses/by/4.0/

\begin{abstract}
Purpose: Mobile banking is the latest and most innovative service offered by Banks. The purpose of the study is to investigate the determinants of service quality of mobile banking services in ICICI. Methodology: This study was conducted by using empirical research and Cluster cum Simple random sampling method has been adopted for a sample size of 100 respondents using mobile banking services in ICICI bank Limited. Findings: 35 percent of the respondents are using the SMS mode of mobile banking services. The dimensions of service quality factors of mobile banking services maintained by ICICI Bank Ltd are Convenience, Responsiveness, Security, Accessibility, Assurance, Knowing the customer and efficiency mobile banking services. The factors that satisfy the customers' level towards mobile banking services offered by ICICI Bank Ltd. are banking activities, banking products and other services. The reasons for using mobile banking services are Convenient services, Time-saving and quick service. Originality/Values: This paper shows that the mobile banking service quality dimensions are an important factor to satisfy the customers. The outcomes of this study enhance the knowledge on the performance of ICICI bank as well as customer satisfaction, which are invaluable to all the bank managers and industry players in improving their services.
\end{abstract}

\section{Keywords}

Customer Satisfaction, Service Quality, Mobile Banking Services

\section{Introduction}

Currently, mobile banking is a quite widespread banking system in the world. 
Many banks are started to provide mobile banking services. Mobile banking is a financial transaction conducted by logging on to the bank's website by using a handphone or cell phone [1]. The global smartphone penetration forecast shows that around 50 percent of mobile users worldwide are projected to own a smart device as of 2018 [2]. The mobile phone penetration is rounding up to 67 percent in 2019 [3]. 60 percent of customers have used mobile banking this year to check account balance, view recent transactions, pay bills, transfer funds or other banking needs. 73 percent made a purchase with a mobile app that can be used at many different retailers; 64 percent paid an individual through a bank's app; 62 percent paid an individual through a payment service's app. Smartphones have become more affordable and the falling mobile data prices have helped the internet to reach a bigger mass of the country's huge population. It indicates that there is an increase in mobile penetration in India. This penetration helps to implement the mobile banking system effectively and it will help to bring all sections of people into the banking system.

Mobile banking makes the change in the traditional processing of the bank's works. Mobile banking helps them to transfer and do all the activities in the same place without moving anywhere. Based on the attitude of the customer there is a change in the behaviour banking process with the help of mobile banking which is more comfortable. So, the entire bank started to develop their activities with the help of mobile banking which is effectively used by the customers. Mobile Banking has become one of the important factors that have been effectively used by the consumer, based on this the updating of banks has to be done to retain and satisfy the customers. Mobile Banking updates their products then knowledge of the behavioural intention to adopt mobile with the usage for transfer of amount, funds, credit, debit, etc. So, mobile banking performed between bankers and its customers in the form of Short Message Service (SMS), application-based, the mobile internet, etc., for the purpose of attaining higher levels of customer satisfaction and increased loyalty by providing any time and any where banking results in reduction of administrative expenses, lesser number of branches and lower handling charges with service to the customers.

In the present scenario, the banking sector of India is running in a dynamic challenge concerning both customer base and performance. Service quality is an indispensable competitive strategy to retain the customer base. Banks are trying to focus on customer satisfaction by giving them enhanced quality services. [4] So the study has examined the customer satisfaction and service quality of mobile banking services in ICICI Bank Ltd. The service quality of banking services has been measured using SERVQUAL (service quality) scale. In the present banking system, excellence in customer service and service quality is the most important tool for sustainable business growth.

\section{Theoretical Background}

This study predicts great Mobile banking potential in Indian banks as Indian 
banks will aim to target online banking users without regular access to the internet but are very likely to own mobile devices. This report of Vital Analytics recommended huge potential of mobile banking in India, as the study found that checking account balance is the most frequently cited reason by Urban Indian customers' for using Mobile Banking. This report has found that 40 million Urban Indians used their mobile phones to access their bank account balances followed by accessing the last three transactions [5]. This research work compared the Indian public sector and private sector banks in terms of customer satisfaction and to study the variety of service quality using the SERVQUAL model. This research work uses both the sources of information, i.e. primary and secondary sources and thereafter the SERVQUAL model has been used to identify the discrepancy in the service delivery system. Finally, the study concludes by giving some recommendations to improve in the area where these banks do not meet the expectation of their customers [6]. This paper focuses on adoption and usage of m-banking services among Indian banking industries as well as customers and include the challenges $\&$ difficulties of $m$-banking services like high charges, slow data transmission and insecurity. Customer is not much aware of mobile banking in compare with ATM, credit card, debit card, etc. [7]. This study focuses on m-banking performance with the help of special programmed called clients downloaded to the mobile device. This paper suggests solutions that have been designed to support multiple channels across the entire customer life cycle. This study identifies the mindset and analyses the security issues in Mobile banking among the banking customers in India. Primary data was collected from 65 respondents using an online questionnaire in this study. Secondary data was also used from the website of the Telecom Regulatory Authority of India (TRAI). The findings indicate that most of the respondents are using online banking facility from their respective banks. However, around 25 percent of customers are using Mobile banking and the remaining 75 percent are not [8]. This study examined the adoption and impact of Mobile banking on customers of different banks located in Delhi. A survey opinion of 200 customers was conducted. ANOVA and Factor Analysis have been used and there were five factors identified; Security/Privacy, Reliability, Efficiency and Responsiveness on the basis of understanding of customer's perception regarding Mobile banking. The results indicate that demographic factors can have a significant impact on customer perception [9]. This study also revealed on factors affecting mobile banking services-an empirical study on the adoption of mobile banking mode of services, presently the Internet technology has brought the third revolution to this world. In this study identifies mobile banking technology which is the third era of technology of banking sector after phone and net banking and comparatively its growth is phenomenal when compared to the first two eras. Even in India the Mobile Banking is growing fast because of the world's largest subscriber base in the mobile sector after China [10]. This study focused on changing consumer behaviour for mobile banking services in India that has been explored towards the consumer satisfaction of the new electronic payment service as mo- 
bile banking and the factors influencing the adoption of mobile banking services. [11]. This study explains technologies in the banking sector have made our life very easy. This paper is to find out the awareness and level of Satisfaction towards ICICI bank Customers using ATM Service in Coimbatore city. For this study purpose, primary data were used and 100 respondents were collected in ICICI. Data were tabulated and analysed with the help of statistical tools to achieve the objectives of the study [12].

\section{Empirical Results}

\section{Research Model}

Empirical study has been adopted. This study was conducted to assess and analyse the customer satisfaction and service quality of mobile banking services in ICICI bank ltd in Tiruchirappalli Town. This empirical study was conducted using the following methodology.

\section{Statement of the Problem}

Mobile banking can play a big role in taking banking services to the remote area. The competition in the banking sector is increasing rapidly as the number of players in the industry is increasing. Mobile banking is expected to improve banks service quality in a form of transactional convenience, saving of time, cost and quick transaction alert. Realizing the increase in mobile penetration in India, now banks and other financial institutions are offering various services through mobile phones. Hence, a research study is required to assess the customer satisfaction and service quality of mobile banking service in ICICI bank Limited to find answers for the following questions.

* Are the customers satisfied with the mobile banking services offered by ICICI bank ltd.?

* How is the service quality of mobile banking service maintained in ICICI bank Ltd.?

* What will be the reason for using mobile banking service?

* Whether the customers are facing any problems in mobile banking services offered by ICICI Bank Ltd.?

In order to find out the reasons for the mentioned questions above, the researcher had framed the objectives below.

Objectives of the Study

* To assess customer satisfaction towards mobile banking services offered by ICICI bank Ltd.

* To analyse the mobile banking services under the dimensions of service quality.

* To assess the main reasons for using mobile banking services.

\section{Scope of the Study}

With the increasing penetration and usage of mobile banking, net banking and other internet banking facilities, the concerns with regard to safety and security of online banking transactions have also escalated Bank has advised that all the users and customers should set-up pin/password for mobile banking, reg- 
ister/update the mobile number, e-mail ID for instant alerts keep a track of all banking transactions. Mobile banking as a service has been increasingly accepted as a medium through which customers may operate their account transactions anywhere and anytime. This study is confined to the customers within Tiruchirappalli Town. The study will be able to reveal that increase the level of satisfaction of the customers regarding the mobile banking services and the service quality of the mobile banking in ICICI bank. It also motivates them to use mobile banking services efficiently. It also helps banks to know whether the products or services they are offering are really satisfying the customers' needs. This study brings the attention of management towards the importance of training and development of customers of mobile banking.

\section{Hypothesis}

$\mathrm{H}_{0}{ }^{1}$ : There is a significant association between Monthly income and the period of being a customer at ICICI Bank Ltd.

$\mathrm{H}_{0}^{2}$ : There is a significant difference between age and respondents often use mobile banking services.

\section{Data Collection \& Tools Used}

Both primary and secondary data are used for the study but the analysis was made mainly using primary data. The data regarding customer satisfaction and service quality of ICICI Bank Ltd. were collected through the well-structured questionnaire. The questionnaire was used to collect data from the respondents who are using mobile banking services in ICICI Bank Ltd. in Tiruchirappalli Town. The information has been collected from books, journals and websites from the internet. Percentage analysis, Chi-square, one-way ANOVA and Factor analysis have been used for the analysis and interpretation. The statistical tools are used to analyse the data to answer the objective structure.

\section{Sampling Technique}

A sample of 100 respondents is approached for the study and analysed. Cluster cum simple random sampling technique is used for the survey. Area of the study refers to Tiruchirappalli Town, TamilNadu. There are 12 ICICI branches in Tiruchirappalli Town and the population is $1,167,485$ approximately. The researcher has taken only one branch for this study, i.e. Thillai Nagar branch.

With the known population, the sample size is determined for the study using the following formula by Dr. Todd L. Grande.

$$
n=\frac{\frac{Z^{2} \cdot p(1-p)}{e^{2}}}{1+\left(\frac{Z^{2} \cdot p(1-p)}{e^{2} N}\right)}
$$

where $n=$ sample size, $z=$ confidence level ( $z$ score value), $e=$ margin error, $N=$ population size, $p=$ population percent. Hence the sample size is equal to 385 .

Form the known population of 1,167,485 with 4 percent margin of error at a 95 percent confidence level with 50 percent population. Therefore, the sample size is taken for the study is 100 . 


\section{Limitations of the Study}

The study is limited to the geographical region of Tiruchirappalli town. Due to time constraints, the researcher has collected data from 100 respondents only.

\section{Results}

Table 1 showes that out of 100 respondents, It is inferred that majority of the respondents are in the age group of 21 - 30 years. Majority of the respondents are female. Majority of the respondents are postgraduate. Majority of the respondents are doing business. Majority of the respondents are in the Rs. 20,001 Rs. 50,000. Majority of the respondents have been a customer for $1-5$ years. Majority of the respondents know about the mobile banking services offered by ICICI Bank Ltd through a customer of the bank. Majority of the respondents are using SMS banking mode of mobile banking services.

To identify the service quality of mobile banking services in ICICI bank ltd, the factor analysis technique has been used. The 18 factors are identified namely Q1, Q2, Q3, ... Q18 was given in Table 2.

Table 2 reveals that Kaiser-Meyer-Olkin Measure of Sampling Adequacy (KMO) and Bartlett's test of sphericity has been applied to the resultant correlation matrix to test whether the relationship among the variables has been significant or not as shown in the table. The result of the test shows that with the significant value of 0.000 there is a significant relationship among the variables chosen. KMO test has yielded a result of 0.561 which states that service analysis can be carried out appropriately for these variables that are taken for the study.

Table 3 observes that the reliability of coefficient alpha $(\alpha)$ for the 100 cases of 18 items is 0.736 (scale range from 0.0 to 1.0 ) which shows the reliability of the given factors.

Table 4 illustrates that the principal component analysis and rotated factors loading method is used for stimulating factors. It is observed that out of 18 services, 7 factors are identified by the rotation method. The total percentage of variation in the factors shows 67.114 percent.

Table 5 shows that clustering for service quality of mobile banking services in ICICI bank Limited. It shows that variables 3 qualities Q8, Q13, Q17 are cluster as factor 1 and is named as "Convenience". The next 4 variables Q6, Q11, Q14, and Q18 are cluster as Factor 2 and are named as "Responsiveness". The next 3 variables Q9, Q10, Q12 are cluster as Factor 3 and are named as "Security". The next 3 variables Q1, Q2, Q15 are cluster as Factor 4 and are named as "Accessibility". The next 2 variables Q4, Q7 are cluster as Factor 5 and are named as "Assurance". The next 2 variables Q5, Q16 are cluster as Factor 6 and are named as "Knowing the Customer". The next 1 variable Q3 is cluster as Factor 7 and is named as "Efficiency".

Hence the factor that stimulates the service quality of mobile banking services in ICICI bank limited is given below:

1) Convenience; 
Table 1. Demographic of the respondents.

\begin{tabular}{|c|c|c|c|}
\hline Factors & Classification & Frequency & Percent \\
\hline \multirow{3}{*}{ Gender } & Male & 47 & 47 \\
\hline & Female & 53 & 53 \\
\hline & Total & 100 & 100 \\
\hline \multirow{6}{*}{ Age (In Years) } & Below 20 years & 5 & 5 \\
\hline & 21 to 30 years & 38 & 38 \\
\hline & 31 to 40 years & 28 & 28 \\
\hline & 41 to 50 years & 19 & 19 \\
\hline & Above 51 years & 10 & 10 \\
\hline & Total & 100 & 100 \\
\hline \multirow{6}{*}{ Educational Qualification } & Under graduate & 29 & 29 \\
\hline & Postgraduate & 36 & 36 \\
\hline & Professional & 19 & 19 \\
\hline & Diploma & 13 & 13 \\
\hline & Others & 3 & 3 \\
\hline & Total & 100 & 100 \\
\hline \multirow{6}{*}{ Occupation } & Professional & 18 & 18 \\
\hline & Business & 25 & 25 \\
\hline & Government employee & 22 & 22 \\
\hline & Private employee & 23 & 23 \\
\hline & Others & 12 & 12 \\
\hline & Total & 100 & 100 \\
\hline \multirow{5}{*}{$\begin{array}{l}\text { Monthly Income } \\
\text { (In Rupees) }\end{array}$} & Below Rs. 20000 & 23 & 23 \\
\hline & Rs. 20,001 - Rs. 50,000 & 42 & 42 \\
\hline & Rs. 50,001 - Rs. 100,000 & 25 & 25 \\
\hline & Above Rs. 100,001 & 10 & 10 \\
\hline & Total & 100 & 100 \\
\hline \multirow{5}{*}{$\begin{array}{c}\text { Period Of Being A } \\
\text { Customer in ICICI Bank Ltd. }\end{array}$} & Less than 1 years & 16 & 16 \\
\hline & $1-5$ years & 42 & 42 \\
\hline & $6-10$ years & 35 & 35 \\
\hline & Above 10 years & 7 & 7 \\
\hline & Total & 100 & 100 \\
\hline \multirow{6}{*}{$\begin{array}{l}\text { Mobile Banking Services } \\
\text { Offered By ICICI Bank Ltd. }\end{array}$} & Advertisement & 27 & 27 \\
\hline & SMS/E-MAILS & 27 & 27 \\
\hline & Customer of the bank & 30 & 30 \\
\hline & Employees of the bank & 12 & 12 \\
\hline & Others & 4 & 4 \\
\hline & Total & 100 & 100 \\
\hline \multirow{5}{*}{$\begin{array}{l}\text { Mode of Using Mobile } \\
\text { Banking Service }\end{array}$} & Wireless application protocol (WAP) & 33 & 33 \\
\hline & Unstructured supplementary data (USSD) & 8 & 8 \\
\hline & SMS banking & 35 & 35 \\
\hline & Application-based SMS/GPRS & 24 & 24 \\
\hline & Total & 100 & 100 \\
\hline
\end{tabular}

Source: computed from primary data. 
Table 2. Service quality of mobile banking services in ICICI bank Ltd.

\begin{tabular}{ccc}
\hline \multicolumn{3}{c}{ KMO and Bartlett's Test } \\
\hline Kaiser-Meyer-Olkin Measure of Sampling Adequacy. & 0.561 \\
Approx. chi-square & 425.553 \\
Bartlett's Test of Sphericity & df & 153 \\
& Sig. & $(0.000)^{\star *}$ \\
\hline
\end{tabular}

Table 3. Reliability analysis on service quality.

\begin{tabular}{ccc}
\hline No. of Cases & No. of Items & Reliability Coefficient Alpha \\
\hline 100 & 18 & 0.736 \\
\hline
\end{tabular}

Table 4. Rotated factor loadings on service quality.

\begin{tabular}{|c|c|c|c|c|c|c|c|}
\hline \multirow{2}{*}{ Service Quality } & \multicolumn{7}{|c|}{ Factors } \\
\hline & 1 & 2 & 3 & 4 & 5 & 6 & 7 \\
\hline $\begin{array}{c}\text { Provide relevant \& } \\
\text { accurate information-Q1 }\end{array}$ & & & & 0.637 & & & \\
\hline $\begin{array}{l}\text { Update technology } \\
\text { regularly-Q2 }\end{array}$ & & & & 0.771 & & & \\
\hline $\begin{array}{l}\text { Maintaining accurate } \\
\text { record-Q3 }\end{array}$ & & & & & & & 0.868 \\
\hline $\begin{array}{l}\text { The bank is willing to } \\
\text { help customers and provide } \\
\text { prompt service-Q4 }\end{array}$ & & & & & 0.631 & & \\
\hline $\begin{array}{l}\text { Get Immediate help for } \\
\text { problem or queries-Q5 }\end{array}$ & & & & & & 0.692 & \\
\hline $\begin{array}{l}\text { Prompt responses to the } \\
\text { requests by SMS/email } \\
\text { or other means-Q6 }\end{array}$ & & 0.643 & & & & & \\
\hline $\begin{array}{l}\text { Mobile hackers may not take } \\
\text { control of my account-Q7 }\end{array}$ & & & & & 0.774 & & \\
\hline Safe to do transactions-Q8 & 0.697 & & & & & & \\
\hline $\begin{array}{l}\text { Secure credit/debit card or } \\
\text { other pin information-Q9 }\end{array}$ & & & 0.547 & & & & \\
\hline Save time-Q10 & & & 0.762 & & & & \\
\hline $\begin{array}{l}\text { Information content and texts } \\
\text { are easy to understand-Q11 }\end{array}$ & & 0.559 & & & & & \\
\hline $\begin{array}{l}\text { Reading characters on } \\
\text { the website is easy-Q12 }\end{array}$ & & & 0.682 & & & & \\
\hline $\begin{array}{l}\text { Availability of customer } \\
\text { service for } 24^{*} 7-\mathrm{Q} 13\end{array}$ & 0.832 & & & & & & \\
\hline
\end{tabular}




\section{Continued}

\begin{tabular}{|c|c|c|c|c|c|c|c|}
\hline $\begin{array}{c}\text { Anywhere and } \\
\text { anytime banking-Q14 }\end{array}$ & & 0.725 & & & & & \\
\hline $\begin{array}{l}\text { Solve the banking } \\
\text { problems quickly-Q15 }\end{array}$ & & & & 0.721 & & & \\
\hline $\begin{array}{l}\text { Easy to contact } \\
\text { the bank-Q16 }\end{array}$ & & & & & & 0.783 & \\
\hline $\begin{array}{l}\text { Speed of login to } \\
\text { account is fast-Q17 }\end{array}$ & 0.513 & & & & & & \\
\hline $\begin{array}{c}\text { Reducing the } \\
\text { waiting time-Q18 }\end{array}$ & & 0.589 & & & & & \\
\hline Percentage of Variance & 11.124 & 10.628 & 10.522 & 9.764 & 8.780 & 8.686 & 7.609 \\
\hline Cumulative percentage & 11.124 & 21.752 & 32.774 & 42.038 & 50.818 & 59.505 & 67.114 \\
\hline
\end{tabular}

Source: primary data. Extraction method: principal Component Analysis.

Table 5. Clustering of stimulating factor in service quality of mobile banking services in ICICI bank ltd.

\begin{tabular}{|c|c|c|}
\hline Factor & Particulars & $\begin{array}{l}\text { Rotated Factor } \\
\text { Loadings }\end{array}$ \\
\hline \multirow{3}{*}{$\begin{array}{l}\text { 1) Convenience } \\
\text { (11.124 Percent) }\end{array}$} & Safe to do transactions-Q8 & 0.697 \\
\hline & Availability of customer service for $24^{*} 7-\mathrm{Q} 13$ & 0.832 \\
\hline & Speed of login to account is fast-Q17 & 0.513 \\
\hline \multirow{4}{*}{$\begin{array}{l}\text { 2) Responsiveness } \\
\text { (10.628 Percent) }\end{array}$} & $\begin{array}{l}\text { Prompt responses to the requests by } \\
\text { SMS/email or other means-Q6 }\end{array}$ & 0.643 \\
\hline & $\begin{array}{l}\text { Information content and texts are easy to } \\
\text { understand-Q11 }\end{array}$ & 0.559 \\
\hline & Anywhere and anytime banking-Q14 & 0.725 \\
\hline & Reducing the waiting time-Q18 & 0.589 \\
\hline \multirow{3}{*}{ 3) Security (10.522 Percent) } & $\begin{array}{l}\text { Secure credit/debit card or } \\
\text { other pin information-Q9 }\end{array}$ & 0.547 \\
\hline & Save time-Q10 & 0.762 \\
\hline & Reading characters on the website is easy-Q12 & 0.682 \\
\hline \multirow{3}{*}{$\begin{array}{l}\text { 4) Accessibility } \\
\text { (9.764 Percent) }\end{array}$} & Provide relevant \& accurate information-Q1 & 0.637 \\
\hline & Update technology regularly-Q2 & 0.771 \\
\hline & Solve the banking problems quickly-Q15 & 0.721 \\
\hline \multirow{2}{*}{ 5) Assurance (8.780 Percent) } & $\begin{array}{l}\text { The bank is willing to help customers } \\
\text { and provide prompt service-Q4 }\end{array}$ & 0.631 \\
\hline & $\begin{array}{l}\text { Mobile hackers may not take control of } \\
\text { my account-Q7 }\end{array}$ & 0.774 \\
\hline \multirow{2}{*}{$\begin{array}{l}\text { 6) Knowing the Customer } \\
\text { (8.686 Percent) }\end{array}$} & Get Immediate help for problem or queries-Q5 & 0.692 \\
\hline & Easy to contact the bank-Q16 & 0.783 \\
\hline 7) Efficiency (7.609 Percent) & Maintaining accurate record-Q3 & 0.868 \\
\hline
\end{tabular}


2) Responsiveness;

3) Security;

4) Accessibility;

5) Assurance;

6) Knowing the Customer;

7) Efficiency.

To identify the respondents' level of satisfaction towards the mobile banking service in ICICI bank ltd, the factor analysis technique has been used. The 10 factors are identified namely S1, S2, S3, ... S10 was given in Table 6.

Table 6 reveals that Kaiser-Meyer-Olkin Measure of Sampling Adequacy (KMO) and Bartlett's test of sphericity has been applied to the resultant correlation matrix to test whether the relationship among the variables has been significant or not as shown in the table. The result of the test shows that with the significant value of 0.000 there is a significant relationship among the variables chosen. KMO test has yielded a result of 0.621 which states that service analysis can be carried out appropriately for these variables that are taken for the study.

Table 7 observes that the reliability of coefficient alpha $(\alpha)$ for the 100 cases of 10 items is 0.661 (scale range from 0.0 to 1.0 ) which shows the reliability of the given factors.

Table 8 illustrates that the principal component analysis and the rotated factor loading method is used for stimulating factors. It is observed that out of 10 services, 4 components are identified by the rotation method. The total percentage of variation in the factors shows 63.563 percent.

Table 9 shows that clustering of stimulating factor in the level of satisfaction towards mobile banking services in ICICI bank limited. It shows that variables 4 services Q2, Q3, Q7 and Q9 are cluster as factor 1 and is named as "Banking activities". The next 3 variables Q1, Q5, Q8 are cluster as factor 2 and is named as "Banking products". The next 2 variables Q6, Q10 are cluster as factor 3 and is named as "Other services". The next 1 variable Q4 is cluster as factor 4 and is named as "Other services".

Table 6. Respondents level of satisfaction towards the mobile banking services in ICICI bank Ltd.

\begin{tabular}{ccc}
\hline \multicolumn{3}{c}{ KMO and Bartlett's Test } \\
\hline Kaiser-Meyer-Olkin Measure of Sampling Adequacy. & 0.621 \\
Bartlett's Test of Sphericity & Approx. chi-square & 161.621 \\
& df & 45 \\
Sig. & $(0.000)^{* *}$
\end{tabular}

Table 7. Reliability analysis of level of satisfaction.

\begin{tabular}{ccc}
\hline No of Cases & No of Items & Reliability Coefficient Alpha \\
\hline 100 & 10 & 0.661 \\
\hline
\end{tabular}


Table 8. Rotated factor loadings on level of satisfaction.

\begin{tabular}{ccccc}
\hline Particulars & \multicolumn{4}{c}{ Factors } \\
\cline { 2 - 4 } & 1 & 2 & 3 & 4 \\
\hline Monitoring of term deposits-Q1 & & 0.832 & \\
Cards services \& Card transfer-Q2 & 0.718 & & 0.813 \\
Fund transfer-Q3 & 0.546 & & \\
Payments (Mobile Recharge, & & & & \\
Bills payments \& Tax payments)-Q4 & & & & \\
Checking of accounts History and \\
mini statement-Q5
\end{tabular}

Source: primary data. Extraction method: principal component analysis.

Table 9. Clustering of stimulating factor in level of satisfaction towards mobile banking services in ICICI bank limited.

\begin{tabular}{|c|c|c|}
\hline Factor & Particulars & Rotated Factor Loadings \\
\hline \multirow{4}{*}{$\begin{array}{l}\text { 1) Banking Activities } \\
\text { (19.724 Percent) }\end{array}$} & Cards services \& card transfer-Q2 & 0.718 \\
\hline & Fund transfer-Q3 & 0.546 \\
\hline & Change of PIN, provisions-Q7 & 0.771 \\
\hline & Mutual funds statement-Q9 & 0.630 \\
\hline \multirow{3}{*}{$\begin{array}{l}\text { 2) Banking Products } \\
\text { (16.003 Percent) }\end{array}$} & Monitoring of term deposits-Q1 & 0.832 \\
\hline & $\begin{array}{l}\text { Checking of accounts history } \\
\text { and mini statement-Q5 }\end{array}$ & 0.470 \\
\hline & Immediate payment service (IMPS)-Q8 & 0.709 \\
\hline \multirow{2}{*}{$\begin{array}{l}\text { 3) Other Services } \\
\text { (14.670 Percent) }\end{array}$} & Cheque book request-Q6 & 0.801 \\
\hline & $\begin{array}{l}\text { SMS alter about bank services } \\
\text { and update new product-Q10 }\end{array}$ & 0.740 \\
\hline $\begin{array}{l}\text { 4) Other Services } \\
\text { (13.166 Percent) }\end{array}$ & $\begin{array}{c}\text { Payments (mobile recharge, } \\
\text { bills payments \& tax payments)-Q4 }\end{array}$ & 0.813 \\
\hline
\end{tabular}

Hence the factor that stimulates the level of satisfaction towards mobile banking services in ICICI bank limited is given below:

1) Banking activities;

2) Banking products; 
3) Other services;

4) Other services.

To identify the reasons for using mobile banking service, the factor analysis technique has been used. The 7 factors are identified namely F1, F2, F3, ... F7 was given in Table 10.

Table 10 reveals that Kaiser-Meyer-Olkin Measure of Sampling Adequacy (KMO) and Bartlett's test of sphericity has been applied to the resultant correlation matrix to test whether the relationship among the variables has been significant or not as shown in the table. The result of the test shows that with the significant value of 0.000 there is a significant relationship among the variables chosen. KMO test has yielded a result of 0.639 which states that service analysis can be carried out appropriately for these variables that are taken for the study.

Table 11 observes that the reliability of coefficient alpha $(\alpha)$ for the 100 cases of 7 items is 0.697 (scale range from 0.0 to 1.0 ) which shows the reliability of the given factors.

Table 12 illustrates that the principal component analysis and rotated factors loading method is used for stimulating factors. It is observed that out of 7 factors, 3 factors are identified by the rotation method. The total percentage of variation in the factors shows 68.789 percent.

Table 10. Reasons for using mobile banking services.

\begin{tabular}{ccc}
\hline \multicolumn{3}{c}{ KMO and Bartlett's Test } \\
\hline Kaiser-Meyer-Olkin Measure of Sampling Adequacy. & 0.639 \\
Bartlett's Test of Sphericity & Approx. chi-square & 136.105 \\
& $\mathrm{df}$ & 21 \\
\hline
\end{tabular}

Table 11. Reliability analysis on reasons.

\begin{tabular}{ccc}
\hline No of Cases & No of Items & Reliability Coefficient Alpha \\
\hline 100 & 7 & 0.697 \\
\hline
\end{tabular}

Table 12. Rotated factor loadings on reasons.

\begin{tabular}{cccc}
\hline Reasons & \multicolumn{3}{c}{ Factors } \\
\cline { 2 - 4 } & 1 & 2 & 3 \\
\hline Immediate-R1 & & 0.766 & \\
Time Saving-R2 & 0.863 & \\
Simple Mechanism-R3 & 0.845 & & \\
Low Cost-R4 & & 0.305 & \\
Fast Responses-R5 & & & \\
Quick Service-R6 & 0.620 & & 17.648 \\
Convenient Device-R7 & 29.940 & 21.201 & 68.789 \\
Percentage of Variance & 29.940 & 51.141 & \\
Cumulative Percentage & & & \\
\hline
\end{tabular}

Source: primary data. Extraction method: principal component analysis. 
Table 13 shows that clustering of stimulating factor in reasons for using mobile banking services. It reveals that 3 factors are identified as being the maximum percent variance accounted. The 3 Reasons R3, R4, R7 are cluster as factor 1 and is named as "Convenient service". The next 3 Reasons R1, R2, R5 are cluster as factor 2 and is named as "Time saving". The next 1 Reasons R6 are cluster as factor 3 and is named as "Quick service".

Hence the reasons for using mobile banking services are given below:

1) Convenient service;

2) Time-saving;

3) Quick services.

Table 14 shows the results of the association between monthly income and long customers in ICICI Bank Ltd. Hence the chi-square value is significant at 0.001 percent level. Therefore, $\mathrm{H}_{1}$ alternative hypothesis is accepted and it is concluded there is a significant association between mobile income and long customer in ICICI bank ltd.

A one-way ANOVA was done with age as an independent variable and often used as mobile banking services dependent variable.

Table 15 depicts the age and respondents often use mobile banking services. The significant at 0.10 percent level since $\mathrm{H}_{1}$ alternative hypothesis is accepted. Therefore, it is concluded that there is a significant difference between age and respondents often use mobile banking services.

Table 13. Clustering of stimulating factor $\mathrm{n}$ reasons for using mobile banking services.

\begin{tabular}{lcc}
\hline \multicolumn{1}{c}{ Factor } & Particulars & Rotated Factor Loadings \\
\hline \multirow{2}{*}{ 1) Convenient Service } & Simple Mechanism-R3 & 0.745 \\
(29.940 Percent) & Low Cost-R4 & 0.845 \\
& Convenient Device-R7 & 0.620 \\
2) Time Saving (21.201 Percent) & Immediate-R1 & 0.766 \\
& Time Saving-R2 & 0.863 \\
3) Quick Services (17.648 Percent) & Fast Responses-R5 & 0.305 \\
\hline
\end{tabular}

Table 14. Respondents monthly income and long customer in ICICI bank Ltd.

\begin{tabular}{|c|c|c|c|c|c|c|}
\hline \multirow{2}{*}{$\begin{array}{c}\text { Long Customer } \\
\text { in ICICI } \\
\text { Bank Ltd. }\end{array}$} & \multicolumn{5}{|c|}{ Monthly Income } & \multirow[b]{2}{*}{ Total } \\
\hline & $\begin{array}{c}\text { Below } \\
\text { Rs. } 20,000\end{array}$ & Rs. 20,001 - & Rs. 50,000 RS. 50,001 & - RS. 100,000 & $\begin{array}{c}\text { Above } \\
\text { Rs. } 100,001\end{array}$ & \\
\hline Less than 1 Years & 9 & 6 & & 1 & 0 & 16 \\
\hline 1 - 5 Years & 5 & 28 & & 8 & 1 & 42 \\
\hline $6-10$ Years & 8 & 8 & & 12 & 7 & 35 \\
\hline Above 10 Years & 1 & 0 & & 4 & 2 & 7 \\
\hline Total & 23 & 42 & & 25 & 10 & 100 \\
\hline $\begin{array}{c}\text { Pearson } \\
\text { Chi-Square }\end{array}$ & \multicolumn{6}{|c|}{$39.223^{\mathrm{a}}$} \\
\hline Sig. & \multicolumn{6}{|c|}{$\left(0.000^{* *}\right)$} \\
\hline
\end{tabular}

Source: primary data. ${ }^{*}$ Sig @ 0.001 percent level. 
Table 15. Age and respondents often use mobile banking services.

\begin{tabular}{cccc}
\hline Often Using Mobile Banking Services & Mean Square & F & Sig. \\
\hline Between Groups & 1.936 & 2.590 & $\left(0.042^{\star}\right)$ \\
Within Groups & 0.747 & & \\
\hline
\end{tabular}

Source: primary data. ${ }^{\star}$ Sig at 0.05 percent level.

\section{Findings}

The majority ( 38 percent) of the respondents are in the age group of $21-30$ years. The majority ( 53 percent) of the respondents are female. The majority (36 percent) of the respondents are postgraduate. The majority ( 25 percent) of the respondents are doing business. The majority ( 42 percent) of the respondents earn a monthly income Rs. 20,001 - Rs. 50,000. The majority (42 percent) of the respondents have been a customer for 1 - 5 years. The majority (30 percent) of the respondents know about the mobile banking services offered by ICICI bank limited through the customer of the bank. The majority (35 percent) of the respondents are using SMS banking mode of banking services. Convenience, Responsiveness, Security, Accessibility, Assurance, Knowing the customer and efficiency are the dimensions of service quality factors of mobile banking services maintained by ICICI Bank Ltd. Banking activities, Banking Products, Other services and other services are the factors that satisfy the customers level towards mobile banking services offered by ICICI Bank Ltd. Convenient services, Time-saving and quick service are the reasons for using mobile banking services. The result of the chi-square is significant at 0.001 percent level. Hence, $\mathrm{H}_{1}$ alternative hypothesis is accepted. Therefore, there is a significant association between monthly income and long customer in ICICI Bank Ltd. The result of one-way ANOVA is significant at 0.10 percent level. Hence $\mathrm{H}_{1}$ alternative hypothesis is accepted. Therefore, there is a significant difference between age and respondents often use mobile banking services.

\section{Conclusion}

With the increasing levels of globalization of the Indian banking industry, the competition in the banking industry has intensified. Nowadays it turns into a real form of banking is "Anytime and anywhere" banking. Service quality now acts as a competitive weapon. The present study reveals that the majority of respondents are satisfied with the banking activities, banking products, other services, and other services provided by ICICI mobile banking services. The factor analysis indicates that service quality of mobile banking services in ICICI bank Ltd convenience, responsiveness, security, accessibility, assurance, knowing the customer and efficiency are the major factors responsible for customer satisfaction of service quality stood at 67.114 percent regarding the services provided by ICICI Bank Ltd. Thus based on the percent level of customer satisfaction in ICICI Bank Ltd has a scope to improve the quality of the mobile banking service rendered to its customers to ensure their loyalty. To improve the service quality 
bank can improve the security and reductions in risk through mobile devices are building the customer trust in mobile banking services. So bank must be careful about the security issues. Customer support for guiding the mobile banking application uses enhances the customer satisfaction and trust in bank and applications as well. The accessing of mobile banking should be still more convenient devices needed. Therefore creating awareness to inform the public about the benefits derived on the mobile banking services product.

\section{Scope for Further Research}

Further research can be done in bank wise study on service quality dimensions. The mobile banking adoption and its opportunities and challenges can be explored. The qualitative research and quantitative research was done to develop the service quality measurement scale. So that future studies can think of improvement of the scale.

\section{Conflicts of Interest}

The authors declare no conflicts of interest regarding the publication of this paper.

\section{References}

[1] Tugiramasiko, M. (2018) Analysing Factors Affecting Mobile Banking of Commercial Banks in Uganda: Case of Centenary Bank Uganda Limited, Kireka Branch. Makerere University, Kampala.

http://dspace.mak.ac.ug/bitstream/handle/10570/6931/Tugiramasiko-cobams-mfs.p $\underline{\mathrm{df} \text { ? sequence }=1 \text { \&isAllowed }=\mathrm{y}}$

[2] https://www.statista.com/statistics/257048/smartphone-user-penetration-in-india/

[3] https://www.statista.com/statistics/274774/forecast-of-mobile-phone-users-worldwi de/

[4] Sivesan, S. (2012) Service Quality and Customer Satisfaction: A Case Study-Banking Sectors in Jaffna District, Sri Lanka. International Journal of Marketing, Financial Services \& Management Research, 1, 1-9.

[5] Charul, V. (2009) Mobile Banking in India. Perception \& Statistics Vital Analytics.

[6] Khatri, P. and Ahua, Y. (2010) Comparative Study of Customer Satisfaction in Indian Public Sector and Private Sector Banks. International Journal of Engineering and Management Sciences, 1, 42-50.

[7] Uppal, R. (2011) Mobile Banking in India: An Empirical Analysis. In: Banking with technology, Udaipur, India, 29-36.

[8] Gamoorthy Avinanya, S.A. (2012) Mobile Banking: An Analysis. Asian Journal of Research in Banking and Finance, 1, 56-66.

[9] Devadevan, V. (2013) Mobile Banking in India: Issues and Challenges. International Journal of Emerging Technology and Advanced Engineering, 3, 516-520.

[10] Shamser, S. (2014) The Impact and Adoption of Mobile Banking in Delhi. International Research Journal of Business and Management, 1, 19-31.

[11] Balakrishnan, L. (2016) Factors Affecting Mobile Banking Services: An Empirical Study. ISBR Management Journal Research Center, 1, 23-29. 
[12] Suresh, A.S. and Singh, T. (2017) A Study of Changing Consumer Behaviour for Mobile Banking Service in India. International Journal of Arts, Management and Humanities, 6, 72-75. 